\title{
Originals
}

\section{Studies on the betacellulin receptor in pancreatic AR42J cells}

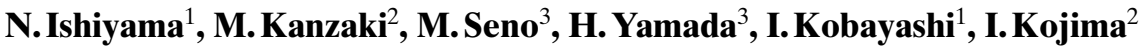 \\ ${ }^{1}$ Department of Laboratory Medicine, Gunma University School of Medicine, Maebashi, Japan \\ ${ }^{2}$ Institute for Molecular and Cellular Regulation, Gunma University, Maebashi, Japan \\ ${ }^{3}$ Department of Bioengineering Science, Faculty of Engineering, Okayama University, Okayama, Japan
}

\begin{abstract}
Summary Betacellulin is a member of the epidermal growth factor family and converts pancreatic AR42J cells into insulin-producing cells. This study was conducted to characterise the receptor for betacellulin in AR42J cells. AR42J cells expressed two classes of binding sites for radioactive iodine labelled betacellulin, with $\mathrm{Kd}$ values of $4.6 \times 10^{-11} \mathrm{~mol} / \mathrm{l}$ and $3.0 \times 10^{-10} \mathrm{~mol} / \mathrm{l}$. The binding of $\left.{ }^{[125} \mathrm{I}\right]$ betacellulin was inhibited by unlabelled betacellulin in a dose-dependent manner, but epidermal growth factor was 50 fold less effective than betacellulin. Affinity cross-linking showed a $\left[{ }^{125} \mathrm{I}\right]$ betacellulin-binding protein with a molecular weight of approximately $180 \mathrm{KDa}$. When this protein was immunoprecipitated with antibody against epidermal growth factor receptors ErbB-1, ErbB-2, ErbB-3 or ErbB-4, it was immunoprecipitated only by the anti-ErbB-1 antibody. When the $\left[{ }^{125} \mathrm{I}\right]$ betacellulin-labelled proteins were immunoprecipitated with a combination of the four ErbB antibodies, and the unprecipitated proteins
\end{abstract}

were then immunoprecipitated with anti-phosphotyrosine antibody, a $190 \mathrm{KDa}$ protein was observed. Betacellulin induced the tyrosine phosphorylation of ErbB-1, ErbB-2 and ErbB-4. Finally, while $100 \mathrm{pmol} / \mathrm{l}$ betacellulin converted all of the AR42J into insulin-producing cells in the presence of activin $A, 10 \mathrm{nmol} / 1$ epidermal growth factor induced differentiation in only about $30 \%$ of the cells. Higher concentrations of epidermal growth factor were less effective. Neu differentiation factor in the presence or absence of epidermal growth factor was ineffective. These results indicate that betacellulin binds to ErbB-1 and possibly another protein with a molecular weight of $190 \mathrm{KDa}$. The latter betacellulin-binding protein may be involved in the differentiation-inducing activity of betacellulin.

Keywords Betacellulin, epidermal growth factor, epidermal growth factor receptor, differentiation, ErbB [Diabetologia (1998) 41: 623-628]
Betacellulin (BTC) is a polypeptide growth factor isolated from conditioned medium of $\beta$-TC-3 insulinoma cells [1]. Mouse BTC comprises 80 amino acids and has three potential glycosylation sites. Fifty amino acid residues of the carboxy terminal region of BTC have a strong homology with transforming

Received: 15 October 1997 and in revised form: 5 February 1998

Corresponding author: Dr. I. Kojima, Department of Cell Biology, Institute for Molecular \& Cellular Regulation, Gunma University, Maebashi 371, Japan

Abbreviations: BTC, betacellulin; EGF, epidermal growth factor; TGF- $\alpha$, transforming growth factor $\alpha$. growth factor $\alpha$ (TGF- $\alpha$ ) and heparin-binding epidermal growth factor-like growth factor (HB-EGF) [1]. Six cystein residues found in members of the epidermal growth factor (EGF) family are conserved in BTC. BTC is thus considered to belong to the EGF family. BTC stimulates cell growth in fibroblasts and vascular smooth muscle cells $[1,2]$, and its potency is nearly identical to that of EGF. Consistent with this notion, radioactive iodine labelled BTC binds to the EGF receptor, and the growth promoting action of BTC is inhibited by a blocking antibody against the EGF receptor [2]. These results indicate that BTC stimulates DNA synthesis by acting on the EGF receptor in fibroblasts [2]. Receptors for the EGF family have been characterised extensively with four 
types described to date, including ErbB-1, neu/ErbB2, ErbB-3 (HER3) and ErbB-4(HER4) [3]. EGF and TGF- $\alpha$ bind to ErbB-1, and binding of the ligand results in phosphorylation of ErbB-1 as well as ErbB-2 on tyrosine residues [4]. ErbB-1 and ErbB-2 form heteromeric complex [4]. Recently, it was shown that BTC binds to both ErbB-1 and ErbB-4 and phosphorylates Erb-B1, Erb-B2, Erb-B3 and Erb-B4 in cells transfected with four ErbB proteins [5, 6]. These results suggest that BTC exerts its effect by acting on a unique set of Erb-B proteins.

Pancreatic AR42J-B20 is a subclone of AR42J cells that is derived from an acinar cell tumour [7]. We reported recently that AR42J-B20 cells possess properties characteristic of the putative pancreatic progenitor cells $[8,9]$. Thus, AR42J-B20 cells express proteins specific to both exocrine and neuroendocrine cells [8]. Using recombinant human BTC, we showed that treatment of the cells with BTC and activin A converted AR42J-B20 into insulin-producing cells [9]. Therefore, BTC acts as a differentiation factor rather than a growth factor in these cells. Interestingly, the differentiation-inducing activity of BTC is not reproduced by similar doses of EGF or TGF- $\alpha$ [9]. Hence, BTC seems to exert its action by acting on the receptor system different from the EGF receptor. Since BTC is expressed in fetal pancreas (Miyagawa J, Hanafusa T, Sasada R, et al. unpublished data), it probably plays a critical part in the formation of pancreatic beta cells. It is therefore important to identify the receptor system through which BTC exerts its differentiation-inducing activity. The present study was conducted to characterise the receptor to which BTC binds in AR42J-B20 cells.

\section{Materials and methods}

Materials. Recombinant human BTC was prepared as described previously [10]. Recombinant human activin A was provided by Dr. Y.Eto of Central Research Laboratory, Ajinomoto Inc. (Kawasaki, Japan). EGF was obtained from Upstate Biotechnology Inc. (Lake Placid, N. Y., USA) and Neu differentiation factor was from R \& D Systems Inc. (Minneapolis, Min. USA). Polyclonal sheep anti-EGF receptor antibody was purchased from Seikagaku Kogyo (Tokyo, Japan). Polyclonal rabbit anti-ErbB-2 was from Oncogene Science (Uniondale, N.Y., USA), monoclonal mouse anti-ErbB-3 antibody from Neo Markers (Fremont, Calif., USA), and polyclonal rabbit anti-ErbB-4 antibody from Santa Cruz Biotechnology (Santa Cruz, Calif., USA). Antiphosphotyrosine antibody (PY20) was purchased from ICN Biomedicals Inc. (Costa Mesa, Calif., USA). Na[ $\left.{ }^{125} \mathrm{I}\right]$ and $\left[{ }^{125} \mathrm{I}\right] \mathrm{EGF}$ were obtained from Dupont-New England Nuclear (Boston, Mass., USA).

Cell culture. AR42J-B20 cells [9] were cultured in Dulbecco's modified Eagle's medium (DMEM) containing $20 \mathrm{mmol} / \mathrm{l} \mathrm{He}$ pes/ $\mathrm{NaOH}(\mathrm{pH} 7.4), 5 \mathrm{mmol} / 1 \mathrm{NaHCO}_{3}$, penicillin, streptomycin and $10 \%$ fetal calf serum (FCS) (Flow Laboratory, North Ryde, Australia) under a humidified condition of $95 \%$ air and $5 \% \mathrm{CO}_{2}$.
Measurement of binding of $\left.{ }^{125} I\right] B T C$. Recombinant BTC was iodinated with $\mathrm{Na}\left[{ }^{125} \mathrm{I}\right]$ by using lactoperoxidase as described [11]. Specific activity of $\left[{ }^{125}\right.$ I]BTC ranged from 80000 to $100000 \mathrm{cpm} / \mathrm{ng}$. In preliminary experiments, we measured the time course of $\left[{ }^{125} \mathrm{I}\right] \mathrm{BTC}$ binding at 4,15 and $37^{\circ} \mathrm{C}$. Maximal binding was obtained after incubation for $3 \mathrm{~h}$ at $15^{\circ} \mathrm{C}$ and the binding remained constant for $5 \mathrm{~h}$. All subsequent experiments were performed by incubating for $3 \mathrm{~h}$ at $15^{\circ} \mathrm{C}$. For the Scatchard analysis, cells were plated in 24-well dishes at a density of $5 \times 10^{4}$ cells/well. After the attachment, monolayer cells were washed with the binding buffer containing DMEM, $20 \mathrm{mmol} / \mathrm{l} \mathrm{Hepes} / \mathrm{NaOH}(\mathrm{pH} 7.4)$ and $0.5 \%$ bovine serum albumin (BSA). For displacement analysis, cells were incubated with $1 \mathrm{ng} /$ dish [ $\left.{ }^{125} \mathrm{I}\right] \mathrm{BTC}$ and various concentrations of unlabelled ligand.

Affinity cross-linking. Approximately $10^{7}$ cells were incubated in $100 \mathrm{~mm}$ dishes. Cells were washed and incubated at $15^{\circ} \mathrm{C}$ for $3 \mathrm{~h}$ with buffer containing DMEM, 0.5\% BSA and $100 \mathrm{ng} / \mathrm{dish}\left[{ }^{125} \mathrm{I}\right] \mathrm{BTC}$ in the presence and absence of excess unlabelled BTC or EGF. After washing three times with icecold PBS, disuccinimidyl suberate (DSS), freshly prepared in dimethylsulphoxide, was added to a final concentration of $0.5 \mathrm{mmol} / \mathrm{l}$. The cells were then incubated at $4{ }^{\circ} \mathrm{C}$ for $15 \mathrm{~min}$, during which time they were agitated frequently. The reaction was terminated by the addition of $1 \mathrm{ml}$ of $20 \mathrm{mmol} / 1 \mathrm{Tris} / \mathrm{HCI}$ (pH 7.4) containing $1 \mathrm{mmol} / \mathrm{l}$ EDTA and $0.15 \mathrm{~mol} \mathrm{NaCl}$. Five minutes later, the cells were rendered soluble in $20 \mathrm{mmol} / \mathrm{l}$ Tris/HCI (pH 7.4) containing 1\% (v/v) Triton X-100, 1 mmol/1 phenylmethyl sulphonylfluoride (PMSF) and $1000 \mathrm{U} / \mathrm{ml}$ trypsin inhibitor. The cell suspension was gently stirred at $4{ }^{\circ} \mathrm{C}$ for $30 \mathrm{~min}$ and centrifuged at $15000 \mathrm{rpm}$ at $4{ }^{\circ} \mathrm{C}$ for $10 \mathrm{~min}$ to remove nuclei and cellular debris. The supernatant was mixed with 1 volume of two-fold concentrated electrophoresis buffer in the presence of $50 \mathrm{mmol} / 1 \mathrm{mercaptoethanol,} \mathrm{and} \mathrm{was} \mathrm{boiled}$ for $3 \mathrm{~min}$. Affinity labelled samples were subjected to sodium dodecyl sulphate polyacrylamide gel electrophoresis (SDSPAGE) using $7.5 \%$ polyacrylamide gel. In some experiments, affinity-labelled proteins were immunoprecipitated by using antibodies against ErbB-1, ErbB-2, ErbB-3 and ErbB-4 and separated by SDS-PAGE. A set of prestained molecular weight markers was co-electrophoresed to determine the size of the cross-linked species. After electrophoresis, the gels were fixed, dried and subjected to autoradiography.

Measurement of phosphorylation of ErbB proteins. AR42J cells were starved for $24 \mathrm{~h}$ in serum-free DMEM and treated for $5 \mathrm{~min}$ at $37^{\circ} \mathrm{C}$ with $1 \mathrm{nmol} / \mathrm{l} \mathrm{BTC}$. After washing twice with ice-cold phosphate-buffered saline (PBS), cells were rendered soluble in Triton X-100 extraction buffer $(20 \mathrm{mmol} / \mathrm{l} \mathrm{so-}$ dium phosphate buffer ( $\mathrm{pH} 7.4$ ), $0.68 \mathrm{~mol}$ sucrose, $0.15 \mathrm{~mol}$ $\mathrm{NaCl}, 5 \mathrm{mM}$ EDTA, $50 \mathrm{mmol} / \mathrm{l} \mathrm{NaF}, 5 \mathrm{mmol} / \mathrm{l}$ sodium pyrophosphate, $2 \mathrm{mmol} / \mathrm{l}$ sodium orthovanadate, $1 \mathrm{mg} / \mathrm{ml}$ BSA, $1 \%$ Triton $\mathrm{X}-100,20 \mu \mathrm{g} / \mathrm{ml}$ soyabean trypsin inhibitor, $3 \times 10^{-7} \mathrm{~mol} / \mathrm{l}$ pepstatin, 0.2 trypsin inhibitory $\mathrm{U} / \mathrm{ml}$ aprotinin, $4 \times 10^{-7} \mathrm{M}$ leupeptin, $2 \mu \mathrm{g} / \mathrm{ml}$ iodoacetamide and $1 \mathrm{mmol} / \mathrm{l}$ PMSF) for $20 \mathrm{~min}$ at $4{ }^{\circ} \mathrm{C}$ with constant rotation. The lysates were collected, transferred to an Eppendorf tube, and clarified by centrifugation at $15000 \mathrm{~g}$ for $10 \mathrm{~min}$ at $4{ }^{\circ} \mathrm{C}$ to remove detergent-insoluble material and nuclei. For immunoprecipitation, equal amounts of protein were incubated with antibodies against ErbB-1, ErbB-2, ErbB-3 and ErbB-4 for $3 \mathrm{~h}$ at $4{ }^{\circ} \mathrm{C}$. Immune complexes were collected with protein $\mathrm{G}$-Sepharose, and washed three times with extraction buffer. Bound proteins were released by heating for $3 \mathrm{~min}$ at $95^{\circ} \mathrm{C}$ in sample buffer. Immunoprecipitates were subjected to SDS-PAGE, and proteins were blotted to polyvinylidene difluoride membranes. 


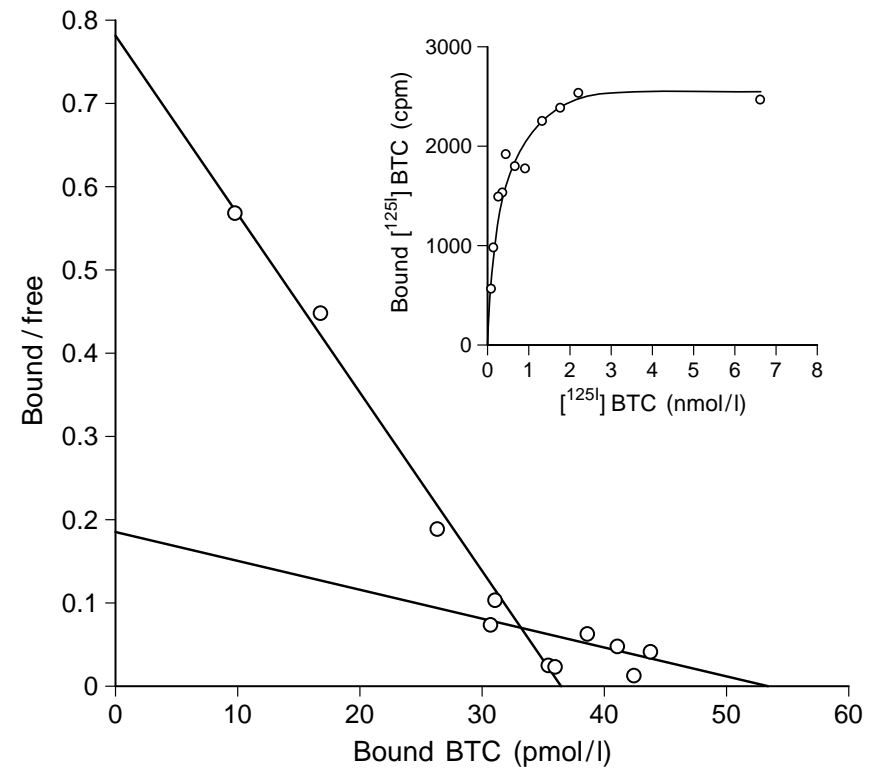

Fig. 1. Scatchard analysis of radioactive iodine labelled ([25I]BTC) binding to AR42J-B20 cells. AR42J-B20 cells were incubated with various concentrations of $\left[{ }^{125} \mathrm{I}\right] \mathrm{BTC}$ and Scatchard analysis was performed. Each determination was done in triplicate. Scatchard analysis was performed three times and the representative of three results was presented. It shows two classes of binding sites

After blocking with $5 \%$ BSA in Rinse buffer $(50 \mathrm{mmol} / \mathrm{l}$ Tris/ $\mathrm{HCl}$ ( $\mathrm{pH} 7.5), 0.75 \mathrm{~mol} / 1 \mathrm{NaCl}, 5 \mathrm{mmol} / \mathrm{l}$ EDTA, $0.25 \%$ Tween 20), the precipitated proteins were detected by Western blotting using antiphosphotyrosine antibody.

Measurement of differentiation. To assess differentiation of AR42J-B20 cells, cells cultured on glass coverslips were incubated for 3 days in DMEM containing $2 \mathrm{nmol} / \mathrm{l}$ activin $\mathrm{A}$ and various concentrations of BTC, EGF, Neu differentiation factor or a combination of Neu differentiation factor and EGF. The cells were fixed and stained with anti-insulin antibody as described [9]. The number of insulin-positive cells was counted. At least 500 cells were examined in each determination [9].

\section{Results}

Binding of $\left[{ }^{125} I\right] B T C$ to AR42J-B20 cells. AR42JB20 cells expressed specific binding sites for $\left[{ }^{125} \mathrm{I}\right] \mathrm{BTC}$. Scatchard analysis showed that AR42J cells possessed two classes of binding sites for $\left[{ }^{125} \mathrm{I}\right] \mathrm{BTC}$ (Fig. 1). Dissociation constants (Kd) for the two binding sites were $(4.6 \pm 0.4) \times 10^{-11} \mathrm{~mol} / \mathrm{l}$ and $(3.0 \pm 0.3) \times 10^{-10} \mathrm{~mol} / \mathrm{l}(n=3$, mean $\pm \mathrm{SD})$. The total binding for high-affinity and low-affinity binding sites were $4800 \pm 300 /$ cell and $2200 \pm 200 /$ cell, respectively $(n=3$, mean $\pm \mathrm{SD})$. The binding of $\left[{ }^{125} \mathrm{I}\right] \mathrm{BTC}$ was not changed significantly in cells pretreated with activin A (data not shown). Figure 2 depicts displacement curves of $\left[{ }^{125} \mathrm{I}\right] \mathrm{BTC}$ binding. The binding of $\left[{ }^{125} \mathrm{I}\right] \mathrm{BTC}$ was displaced by unlabelled

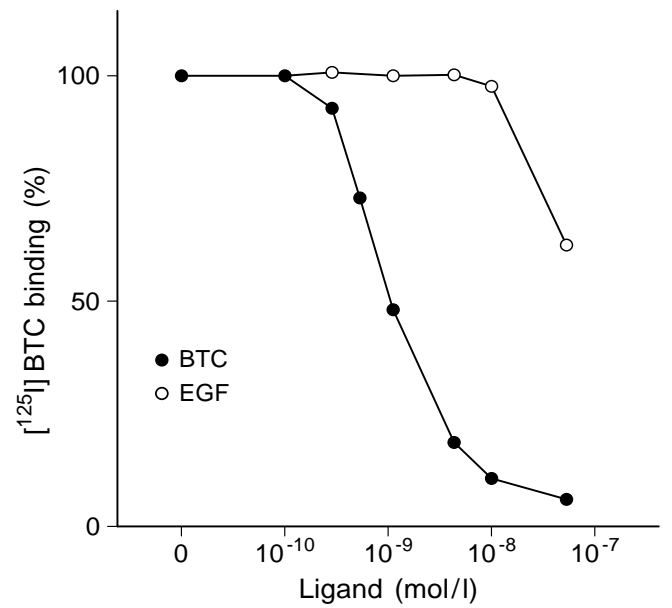

Fig. 2. Displacement of radioactive iodine labelled betacellulin ([125I]BTC) binding by unlabelled ligands. AR42J-B20 cells were incubated with $\left[{ }^{125} \mathrm{I}\right] \mathrm{BTC}$ in the presence of various concentrations of unlabelled BTC or epidermal growth factor (EGF)

BTC in a concentration dependent manner. EGF was less effective than BTC.

Affinity cross-linking of $\left[{ }^{125} I\right] B T C$. Affinity crosslinking of $\left[{ }^{125} \mathrm{I}\right] \mathrm{BTC}$ was performed using DSS. As shown in Fig. $3 \mathrm{~A}$, a $180 \mathrm{KDa}$ protein was labelled with [ $\left.{ }^{125} \mathrm{I}\right] \mathrm{BTC}$. The labelling was blocked by the addition of excess unlabelled BTC, whereas unlabelled excess EGF reduced the labelling only slightly. When a much higher concentration of unlabelled EGF $(1 \mu \mathrm{mol} / \mathrm{l})$ was added, the labelling was inhibited. NDF did not affect the cross-linking of [ ${ }^{125}$ I]BTC. Figure $3 \mathrm{~B}$ shows the dose-response curve for the displacement of [ $\left.{ }^{125} \mathrm{I}\right] \mathrm{BTC}$ cross-linking by unlabelled ligands. To characterise further the receptor to which BTC binds, we immunoprecipitated the proteins cross-linked with $\left[{ }^{125} \mathrm{I}\right] \mathrm{BTC}$ using antibodies against ErbB-1, ErbB-2, ErbB-3 and ErbB-4. As shown in Fig. 4, a [ $\left.{ }^{125} \mathrm{I}\right] \mathrm{BTC}$-labelled protein with a molecular weight of about $180 \mathrm{KDa}$ was precipitated by antiErbB-1, but not by anti-ErbB-2, anti-ErbB-3 or antiErbB-4 antibodies. When the supernatant obtained after the immunoprecipitation with anti-ErbB-1 was applied to SDS-PAGE, a protein band was detected. This protein in the supernatant was not immunoprecipitated with the second application of anti-ErbB-1. Note that in our experimental conditions, each antibody precipitated its own antigen nearly completely since no antigen was left in the supernatant after immunoprecipitation (data not shown). Results shown in Figs. 3 and 4 suggest that, appart from ErbB-1, BTC binds to a protein different from the ErbB proteins. To examine this possibility, we immunoprecipitated the $\left[{ }^{125} \mathrm{I}\right] \mathrm{BTC}$-cross-linked protein with a combination of anti-ErbB-1, anti-ErbB-2, anti-ErbB-3 and anti-ErbB-4 antibodies. The supernatant was immu- 


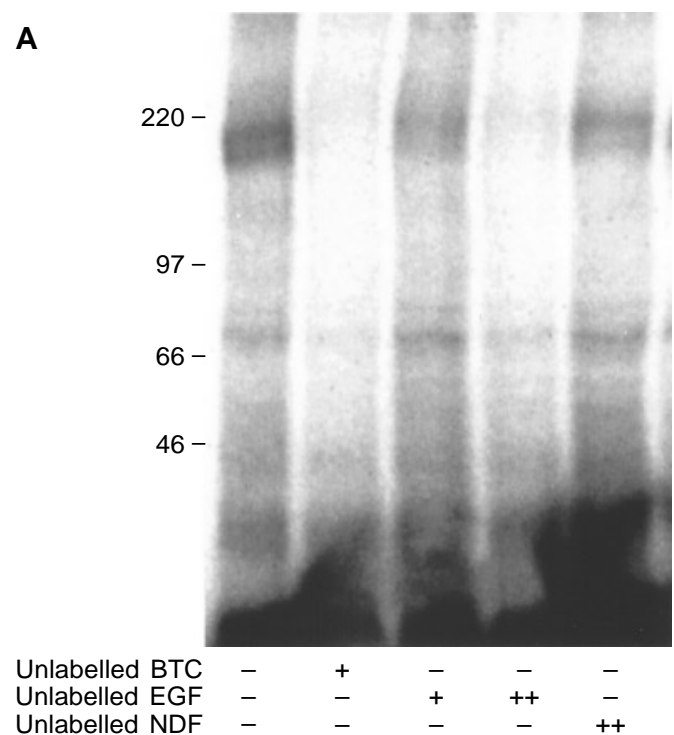

Fig.3 A, B. Affinity cross-linking of AR42J-B20 cells with radioactive iodine labelled betacellulin ([ $\left.\left.{ }^{125} \mathrm{I}\right] \mathrm{BTC}\right)$. A AR42JB20 cells were incubated with $\left[{ }^{125} \mathrm{I}\right] \mathrm{BTC}$ in the presence and absence of excess $(100 \mathrm{nmol} / \mathrm{l})$ unlabelled BTC, epidermal growth factor (EGF) or Neu differentiation factor (NDF). In some experiments, $1 \mu \mathrm{mol} / 1$ unlabelled EGF $(++)$ or NDF $(++)$ was added. Affinity cross-linking was done by using disuccinimidyl suberate, as described in Methods. Cell lysates were separated by SDS-PAGE followed by autoradiography B Cross-linking was performed in the presence and absence of various concentration of BTC (O) or EGF $(\bullet)$ and densitometric analysis was performed.

noprecipitated with antiphosphotyrosine antibody and subjected to SDS-PAGE followed by autoradiography. As shown in Fig. 5, a considerable amount of $\left[{ }^{125} \mathrm{I}\right]-\mathrm{BTC}$-bound protein with a molecular weight of about $190 \mathrm{KDa}$ was left in the supernatant, which was immunoprecipitated with antiphosphotyrosine antibody. The labelling of the $190 \mathrm{KDa}$ protein was inhibited in a dose-dependent manner by the addition of unlabelled BTC during the cross-linking. Note that cross-linking of $190 \mathrm{KDa}$ protein was inhibited to greater extent by $10 \mathrm{nmol} / \mathrm{l}$ unlabelled BTC, suggesting that the $190 \mathrm{KDa}$ protein had higher affinity for BTC than ErbB-1. When similar immunoprecipitation was carried out in Balb/c 3T3 fibroblasts, no $\left[{ }^{125} \mathrm{I}\right] \mathrm{BTC}$-labelled protein remained in the supernatant after precipitation with a combination of the four anti-ErbB antibodies (data not shown).

Phosphorylation of ErbB proteins by BTC. We then studied tyrosine phosphorylation of the ErbB proteins induced by BTC in AR42J-B20 cells. Cells were incubated for $5 \mathrm{~min}$ with $1 \mathrm{nmol} / \mathrm{l} \mathrm{BTC}$, and cell lysates were immunoprecipitated with antibodies against ErbB proteins. Phosphorylation of the ErbB proteins was detected by Western blotting using
B
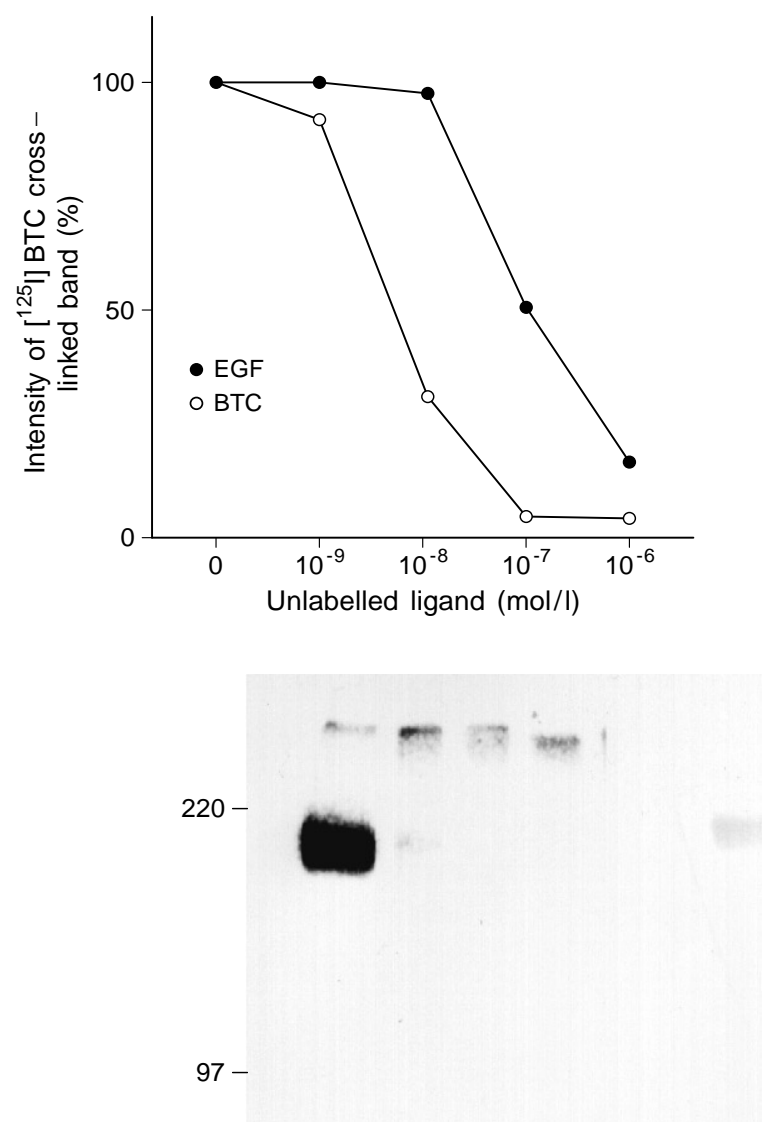

$66-$

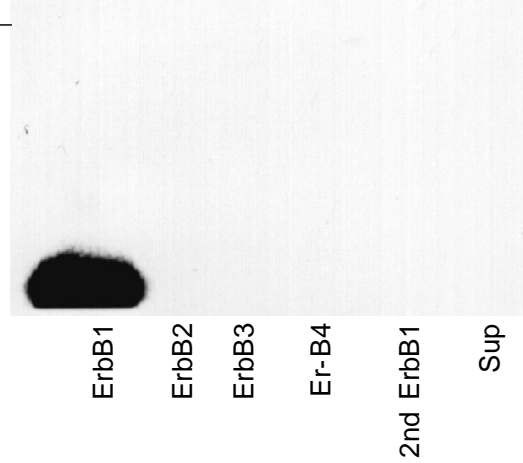

Fig.4. Immunoprecipitation of radioactive iodine labelled betacellulin ([125I]BTC)-labelled protein by anti-Erb antibodies. Affinity cross-linking was done with $\left[{ }^{125} \mathrm{I}\right] \mathrm{BTC}$ by using disuccinimidyl suberate $\left[{ }^{125} \mathrm{I}\right] \mathrm{BTC}$-labelled proteins immunoprecipitated with anti-ErbB-1, anti-ErbB-2, anti-ErbB-3 and antiErbB-4. Immunoprecipitated proteins were subjected to SDSPAGE and an autoradiogram was obtained. The supernatant after immunoprecipitation with anti-ErbB-1 was also applied (Sup). In some experiments, the supernatant was reprecipitated with anti-ErbB-1 antibody (2nd ErbB-1)

anti-phosphotyrosine antibodies. As shown in Fig. 6, $1 \mathrm{nmol} / \mathrm{l}$. BTC induced tyrosine phosphorylation of ErbB-1, ErbB-2 and ErbB-4. In contrast, $1 \mathrm{nmol} / \mathrm{l}$ EGF induced phosphorylation of ErbB-1, but not of ErbB-2 or ErbB-4 (data not shown). 


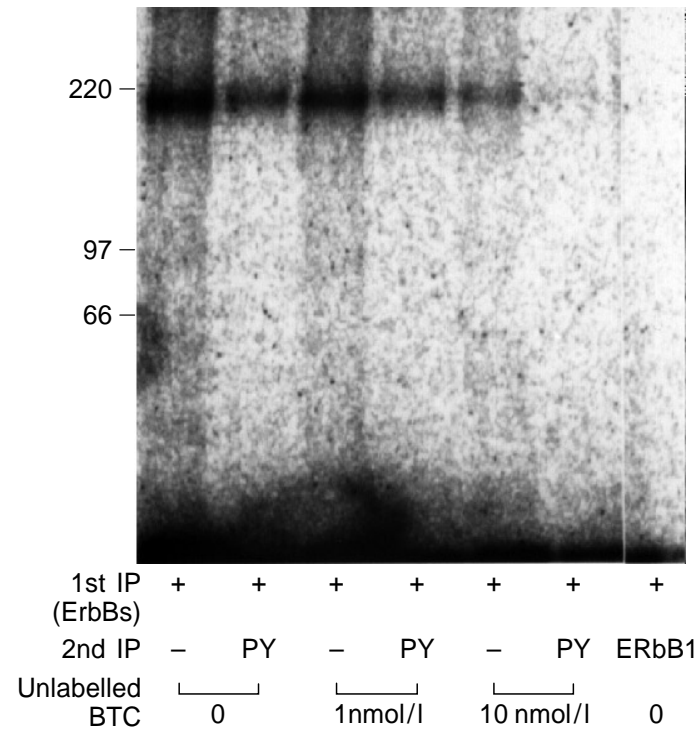

Fig. 5. Radioactive iodine labelled betacellulin ([$\left.{ }^{125} \mathrm{I}\right] \mathrm{BTC}$ )bound protein not immunoprecipitated by anti-ErbB antibodies. Affinity cross-linking with $\left[{ }^{125} \mathrm{I}\right] \mathrm{BTC}$ was done in AR42JB20 cells by using DSS in the presence or absence of various concentration of unlabelled BTC. The cross-linked proteins were immunoprecipitated by a combination of anti-ErbB-1, anti-ErB-2, ErbB-3 and anti-ErbB-4 antibodies. The supernatant was then immunoprecipitated with anti-phosphotyrosine antibody (right). Precipitated proteins were subjected to SDSPAGE followed by autoradiography. The supernatant after the immunoprecipitation with a combination of anti-ErbB antibodies was also applied

Differentiation of AR42J-B20 cells induced by BTC and $E G F$. In our previous study, we showed that AR42J-B20 cells were converted to insulin-producing cells by $1 \mathrm{nmol} / \mathrm{l} \mathrm{BTC}$ in the presence of activin $A$ whereas $1 \mathrm{nmol} / \mathrm{l} \mathrm{EGF}$ was ineffective. In the present study, we examined the effect of various concentrations of BTC and EGF on differentiation of AR42J-B20 cells. As shown in Fig. 7, BTC induced differentiation in a concentration - dependent manner. The effect of BTC was detected at $10 \mathrm{pmol} / \mathrm{l}$. At $100 \mathrm{pmol} / \mathrm{l}$, almost all cells converted to insulinpositive cells. EGF induced differentiation in some of the cells at high concentrations. However, at $50 \mathrm{nmol} / \mathrm{l} \mathrm{EGF}$ induced differentiation in only about $30 \%$ of the cells. At higher concentrations, EGF was less effective. We then examined the effect of Neu differentiation factor on differentiation of AR42JB20 cells. Since Neu differentiation factor induces phosphorylation of ErbB-2 and ErbB-4, (as does BTC [12]), whether or not it can convert AR42JB20 cells into insulin-producing cells is of interest. As shown in Fig.7, Neu differentiation factor did not induce differentiation by itself. Furthermore, it did not enhance the effect of EGF on differentiation. We also tested whether or not antibodies to ErbBs affected the differentiation, but the results were negative.

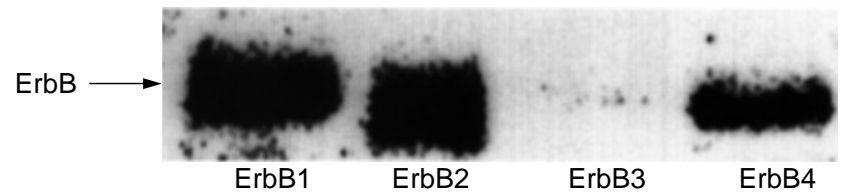

Fig. 6. Phosphorylation of ErbB proteins by betacellulin (BTC). AR42J-B20 cells were incubated for $5 \mathrm{~min}$ with $1 \mathrm{nmol} / \mathrm{l} \mathrm{BTC}$. Cells were lysed and the lysates were immunoprecipitated with anti-ErbB-1, anti-ErbB-2, anti-ErbB-3 and anti-ErbB-4 antibodies. Tyrosine phosphorylated proteins were detected by Western blotting using anti-phosphotyrosine antibody

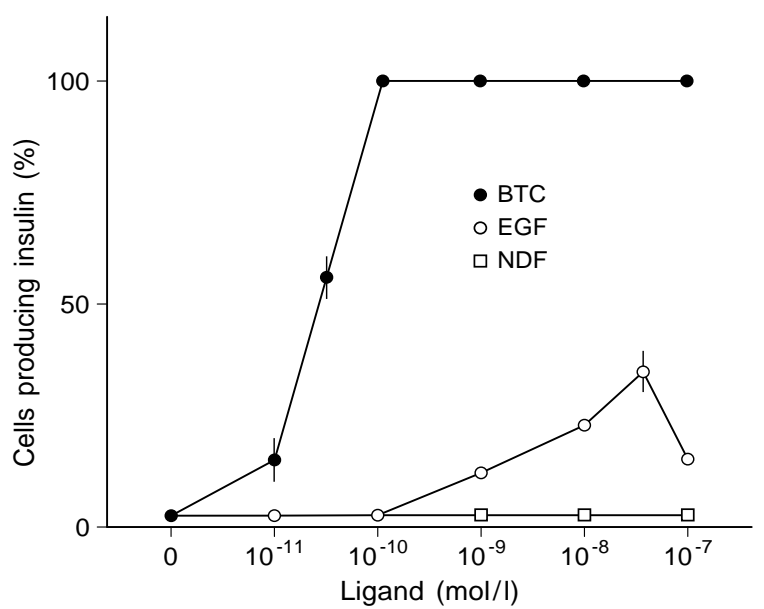

Fig. 7. Effects of betacellulin (BTC), epidermal growth factor (EGF) and Neu differentiation factor (NDF) on differentiation of AR42J-B20 cells. AR42J-B20 cells were incubated for $72 \mathrm{~h}$ with $1 \mathrm{nmol} / \mathrm{l}$ activin $\mathrm{A}$ and various concentrations of BTC, EGF or NDF. Insulin-positive cells were counted. The results are the means \pm SEM of four experiments

\section{Discussion}

In a previous study, we showed that BTC converted pancreatic AR42J-B20 cells into insulin-producing cells [9]. BTC, at a concentration of $100 \mathrm{pmol} / \mathrm{l}$, converts most of the AR42J-B20 cells into insulin-producing cells. In contrast, EFG induces differentiation in only a portion of cells, even at higher concentrations. These results suggest that the effect of BTC is not exerted totally through the EGF receptor. BTC may generate an additional signal that cannot be activated by the EGF receptor. Affinity cross-linking showed that binding of [ $\left.{ }^{125} \mathrm{I}\right] \mathrm{BTC}$ to a $180 \mathrm{KDa}$ protein could not be replaced completely by unlabelled excess EGF. Interestingly, when $\left[{ }^{125} \mathrm{I}\right] \mathrm{BTC}$-cross-linked protein was immunoprecipitated with various ErbB antibodies, the labelled protein was precipitated only by antiErbB-1 antibody. Furthermore, a considerable amount of labelled protein remained unprecipitated in the supernatant when immunoprecipitation was achieved with a combination of anti-ErbB-1, anti- 
ErbB-2, anti-ErbB-3 and anti-ErbB-4 antibodies. It should be noted that in our experimental conditions each antibody nearly completely immunoprecipitates each antigen, since a second precipitation of the supernatant did not provide labelled protein bands. When a similar experiment was carried out in Balb/c 3 T3 cells, no labelled protein was left in the supernatant after immunoprecipitation with the four ErbB antibodies.

These results suggest that a BTC-binding protein not recognised by either of the four anti-ErbB antibodies is expressed in AR42J cells, but not in Balb/c $3 \mathrm{~T} 3$ cells. Because the protein is tyrosine phosphorylated and the molecular weight is about $190 \mathrm{KDa}$, it might be another member of the ErbB family. Ligands belonging to the EGF family induce a complex pattern of changes in phosphorylation of the receptors. For example, when EGF binds to the ErbB-1, ErbB1 is autophosphorylated by the receptor kinase. In addition, EGF also binds to ErbB-2 with lower affinity, and ErbB-2 is then phosphorylated by tyrosine kinase locating in ErbB-1 [4]. This type of regulation is called transmodulation. Similarly, BTC is shown to bind to ErbB-1 and ErbB4 and to induce phosphorylation of ErbB-1, ErbB-2, ErbB-3 and ErbB-4 [5, 6]. In AR42J-B20 cells, BTC bound to ErbB-1 and induced phosphorylation of ErbB-1, ErbB-2 and ErbB-4. The reason for the absence of binding to ErbB-2 and ErbB-4 may be the low sensitivity of the measurement. In this regard, in previous studies on the binding of BTC to ErbB-4, the ErbB-4 gene was introduced into cells by transfection of the cDNA [5, 6]. Presumably, expression of ErbB-4 is quite high in these cells. It is also possible that BTC may bind to an, as yet, unidentified receptor, which transmodulates ErbB-4.

The results shown in Fig. 5 support the possibility that BTC binds to a receptor that has not yet been identified. When immunoprecipitation was done using antibodies against ErbB-1, ErbB-2, ErbB-3 and ErbB-4, a considerable amount of tyrosine-phosphorylated $190 \mathrm{KDa}$ protein remained in the supernatant. It is possible that the unique BTC receptor transmodulates ErbB-4. Scatchard analysis indicated the existence of two classes of binding sites. The affinity of low-affinity binding sites is in the same ranges as that of the EGF receptor in Balb/c 3 T3 cells [2]. It is possible that the high-affinity binding site represent the unique BTC receptor.

When the effect of EGF on the formation of insulin-producing cells was examined, EGF only partially reproduced the effect of BTC even at higher concentrations. This indicates that the signals transduced by the ErbB-1 are not sufficient. BTC also induces phosphorylation of ErbB-2 and ErbB-4. Since Neu differentiation factor cannot induce differentiation by itself, nor enhance the effect of EGF on differentiation, the signals generated through ErbB-4 may not be involved in the effect of BTC on differentiation. Taken together, these results suggest that BTC-in- duced differentiation is mediated at least partly by a unique BTC receptor.

BTC is expressed in human pancreatic islets, insulinoma cells, and nesidioblatosis (Miyagawa J, Hanafusa T, Sasada R, et al. unpublished data). Given the ability of BTC to convert AR42J cells into insulinproducing cells [9], BTC may be involved in the differentiation of pancreatic beta cells in vivo. The receptor system involved in the BTC-mediated differentiation of pancreatic beta cells is therefore potentially important. Identification of the unique BTC receptor may provide a new insight into the mechanism of action of BTC on the differentiation of pancreatic beta cells. Clearly, further studies are necessary to identify the molecular nature of the unique BTC receptor.

Acknowledgements. This study was supported by a Grant-in Aid for Scientific Research from the Ministry of Education, Science, Sports and Culture of Japan, and grants from the Japanese Pancreatic Foundation, the Japanese Diabetes Foundation, the Ciba-Gigy Foundation of Japan, the Uehara Foundation, the Life Science Foundation and the Yamanouchi Foundation for Research on Metabolic Disorders. The authors are grateful to Mami Ozeki for technical assistance and Mayumi Odagiri for secretarial assistance.

\section{References}

1. Shing Y, Christofori G, Hanahan D, Ono Y, Sasada R, Igarashi K, Folkman J (1993) Betacellulin: a mitogen from pancreatic beta cell tumors. Science 259: 1604-1607

2. Watanabe T, Shintani A, Nakata M, Shing Y, Folkman J, Igarashi K, Sasada R (1994) Recombinant human betacellulin. J Biol Chem 269: 9966-9973

3. Prigent SA, Lemoine NR (1992) The type 1 family of growth factor receptors and their ligands. Progress in Growth Factor Research 4: 1-24

4. Mondjtahedi H, Dean C (1994) The receptor for EGF and its ligands. Int J Oncol 4: 277-296

5. Beerli R, Haynes NE (1996) Epidermal growth factor-related peptides activate distinct subsets of ErbB receptors and differ in their biological activities. J Biol Chem 271: 6071-6076

6. Riese D, Bermingham Y, Raaiji TM, Buckley S, Plowman GD, Stern D (1996) Betacellulin activates the epidermal growth factor receptor and ErbB4, and induces cellular response patterns distinct from those stimulated by epidermal growth factor or neuregulin. Oncogene 12: 345-353

7. Christophe J (1994) Pancreatic tumoral cell line AR42J: an amphicrine model. Am J Physiol 266: G963-G971

8. Ohnishi H, Ohgushi N, Tanaka S et al. (1995) Conversion of amylase-secreting rat pancreatic AR42J cells to neuron-like cells by activin A. J Clin Invest 95: 2304-2314

9. Mashima H, Ohnishi H, Wakabayashi K et al. (1996) Betacellulin and activin A coordinately convert amylase-secreting AR42J cells into insulin-secreting cells. J Clin Invest 97: 1647-1654

10. Seno M, Tada H, Kosaka M et al. (1996) Human betacellulin, a member of the EGF family dominantly expressed in pancreas and small intestine, is fully active in a monomeric form. Growth Factors 13: 181-191

11. Kanzaki M, Zhang YQ, Mine T, Kojima I (1994) Stimulation of follistatin production by epidermal growth factor in cultured rat hepatocytes. Biochem Biophys Res Commun 202: 422-428

12. Tzahar E, Levkowitz G, Karunagaran D et al. (1994) ErbB-3 and ErbB-4 function as the respective low and high affinity receptors of all Neu differentiation factor/herregulin isoforms. J Biol Chem 269: 25226-25233 